Research

Open Access

\title{
Inhibition of complement C5a prevents breakdown of the blood-brain barrier and pituitary dysfunction in experimental sepsis
}

\author{
Michael A Flierl'1, Philip F Stahel'1, Daniel Rittirsch 2,5 , Markus Huber-Lang ${ }^{3}$, \\ Andreas D Niederbichler ${ }^{4}$, L Marco Hoesel ${ }^{5}$, Basel M Touban 1 , Steven J Morgan ${ }^{1}$, Wade R Smith ${ }^{1}$, \\ Peter A Ward ${ }^{5}$ and Kyros Ipaktchi ${ }^{1}$
}

\author{
${ }^{1}$ Department of Orthopaedic Surgery, Denver Health Medical Center, University of Colorado School of Medicine, 777 Bannock Street, Denver, CO \\ 80204, USA \\ 2Department of Trauma Surgery, University Hospital Zurich, Rämistrasse 100, 8091 Zurich, Switzerland \\ ${ }^{3}$ Department of Trauma, Hand-, Plastic-, and Reconstructive Surgery, University Hospital Ulm, Steinhövelstrasse 9, 89075 Ulm, Germany \\ ${ }^{4}$ Department of Plastic, Hand, and Reconstructive Surgery, University Medical Center Hannover (MHH), Carl-Neuberg-Strasse 1, 30625 Hannover, \\ Germany \\ ${ }^{5}$ Department of Pathology, University of Michigan Medical School, 1301 Catherine Road, Ann Arbor, Ml 48109, USA
}

Corresponding author: Philip F Stahel, philip.stahel@dhha.org

Received: 27 Oct 2008 Revisions requested: 9 Jan 2009 Revisions received: 12 Jan 2009 Accepted: 6 Feb 2009 Published: 6 Feb 2009

Critical Care 2009, 13:R12 (doi:10.1186/cc7710)

This article is online at: http://ccforum.com/content/13/1/R12

(c) 2009 Flierl et al.; licensee BioMed Central Ltd.

This is an open access article distributed under the terms of the Creative Commons Attribution License (http://creativecommons.org/licenses/by/2.0), which permits unrestricted use, distribution, and reproduction in any medium, provided the original work is properly cited.

\begin{abstract}
Introduction Septic encephalopathy secondary to a breakdown of the blood-brain barrier (BBB) is a known complication of sepsis. However, its pathophysiology remains unclear. The present study investigated the effect of complement $\mathrm{C} 5 \mathrm{a}$ blockade in preventing BBB damage and pituitary dysfunction during experimental sepsis.

Methods Using the standardised caecal ligation and puncture (CLP) model, Sprague-Dawley rats were treated with either neutralising anti-C5a antibody or pre-immune immunoglobulin (Ig) $\mathrm{G}$ as a placebo. Sham-operated animals served as internal controls.

Results Placebo-treated septic rats showed severe BBB dysfunction within 24 hours, accompanied by a significant upregulation of pituitary $\mathrm{C} 5 \mathrm{a}$ receptor and pro-inflammatory cytokine expression, although gene levels of growth hormone were significantly attenuated. The pathophysiological changes in placebo-treated septic rats were restored by administration of neutralising anti-C5a antibody to the normal levels of BBB and pituitary function seen in the sham-operated group.

Conclusions Collectively, the neutralisation of C5a greatly ameliorated pathophysiological changes associated with septic encephalopathy, implying a further rationale for the concept of pharmacological $\mathrm{C} 5 \mathrm{a}$ inhibition in sepsis.
\end{abstract}

\section{Introduction}

Sepsis remains a leading cause of morbidity and mortality in the intensive care unit (ICU), and one of the top 10 causes of death worldwide [1,2]. The underlying pathophysiological cascade of sepsis is highly complex and far from fully understood [3-5]. From an immunological standpoint, the activation of the complement cascade, a potent arm of the innate immune response, has been associated with fatal outcomes in septic patients [6-9]. Particularly, the complement anaphylatoxin C5a, a small inflammatory peptide derived from complement activation, has been characterised as a 'key' mediator of sepsis and septic organ dysfunction [10-14], and was recently labelled as 'too much of a good thing' or to reveal 'a dark side in sepsis' $[15,16]$.

ACTH: adrenocorticotropic hormone; BBB: blood-brain barrier; C5aR: C5a receptor; C5L2: C5a like receptor 2; CLP: caecal ligation and puncture; CNS: central nervous system; $\mathrm{C}_{\mathrm{T}}$ : cycle threshold; EB: Evans Blue; ELISA: enzyme immunosorbent assay; GAPDH: glyceraldehyde 3-phosphate dehydrogenase; GH: growth hormone; ICAM: intracellular adhesion molecule; ICU: intensive care unit; Ig: immunoglobulin; IL: interleukin; MSH: melanocyte-stimulating hormone; PBS: phosphate buffered saline; PCR: polymerase chain reaction; POMC: proopiomelanocortin; RIPA: radio immunoprecipitation assay; TBST: Tris-buffered saline Tween-20; TNF: tumour necrosis factor; VCAM: vascular adhesion molecule 
Although intentionally beneficial, disproportionate activation of complement during sepsis has been found to contribute to thymocyte and adrenomedullary apoptosis [17,18], paralysis of innate immunity $[19,20]$, deterioration of the coagulation/ fibrinolytic system [21] and multiple organ failure [22]. Accordingly, blockade of C5a or its receptors has been shown to prevent multiple organ failure and to greatly attenuate mortality after caecal ligation and puncture (CLP)-induced sepsis $[10,11,14,19,22]$.

Encephalopathy syndrome is a well described complication of sepsis in the ICU. This phenomenon is thought to represent a consequence of inflammation-mediated dysfunction of the blood-brain barrier (BBB), thus allowing neurotoxic mediators to extravasate from the peripheral circulation into the subarachnoid space or into the brain parenchyma. Noteworthy, the focus of research studies have only addressed in more depth the neuro-inflammatory and metabolic intracerebral changes in sepsis [23-29]. The complement anaphylatoxin $\mathrm{C} 5 \mathrm{a}$ has been characterised as a mediator of BBB dysfunction in a variety of central nervous system (CNS) disorders, including traumatic brain injury and bacterial meningitis [30-32]. In addition, the detection of the $\mathrm{C} 5$ a receptor $(\mathrm{C} 5 \mathrm{aR})$ on neurons and the observed upregulation of neuronal $\mathrm{C} 5 \mathrm{aR}$ expression under inflammatory conditions [31,33-35] renders the brain more vulnerable to $\mathrm{C} 5 \mathrm{a}$-mediated neuropathophysiological sequelae secondary to a disruption of the BBB $[30,31,36,37]$. The complement cascade has only recently been implicated in the pathophysiology of septic encephalopathy [38].

Based on the established functions of $\mathrm{C5a}$ in the pathophysiology of sepsis and on experimental data which imply $\mathrm{C} 5 \mathrm{a}$ is a potent mediator of BBB damage and neuroinflammation, we designed the present study to investigate the effect of antibody-mediated C5a-blockade on preventing the development of encephalopathy in experimental sepsis. We hypothesised that blockade of $\mathrm{C} 5 \mathrm{a}$ would reverse the dysfunction of the $\mathrm{BBB}$ and restore the immunological and endocrinological homeostasis in the septic brain.

\section{Materials and methods Experimental CLP model}

All procedures were performed in accordance with the National Institutes of Health guidelines and University Committee on Use and Care of Animals, University of Michigan (UCUCA approval \#8575, 08/11/2008). Specific pathogenfree, adult male Sprague-Dawley rats (Harlan Inc., Indianapolis, IN, USA) weighing 300 to $350 \mathrm{~g}$ were used in all experiments. Sepsis was induced by the CLP procedure as previously described [39]. In brief, rats were anaesthetised with isoflurane (3\%, oxygen flow $3 \mathrm{~L} /$ minute). After abdominal midline incision, the caecum was exposed, ligated and punctured through with a 18-gauge needle, and a small portion of faeces was expressed to ensure potency of the punctures. After repositioning of the bowel, the abdomen was closed in layers using 4-0 surgical sutures (Ethicon Inc., Somerville, NJ, USA) and metallic clips. Sham animals underwent the same procedure except for ligation and puncture of the caecum. Before and after the surgery, animals had unrestricted access to food and water. Where indicated, animals intravenously received $500 \mu \mathrm{g}$ anti-C5a antibody or $500 \mu \mathrm{g}$ preimmune immunoglobulin (Ig) G in $500 \mu$ l sterile Dulbecco's PBS immediately after CLP or sham procedure, as previously described [13].

\section{Anti-C5a antibody}

The neutralising anti-rat C5a antibody used in this study was previously characterised $[10,22]$. In short, rat C5a peptide corresponding to amino acid residues 17 to 36 was coupled to keyhole limpet haemocyanin and used as an antigen to immunise rabbits. After several immunisations, the antibody was affinity purified from serum using the synthetic peptide coupled to beads. Cross-reactivity with recombinant rat C5a was confirmed by Western blotting.

\section{Albumin immunohistochemistry}

Rat brains were surgically removed, embedded in optimal cutting temperature compound (Miles, Elkhart, IN, USA) and stored at $-80^{\circ} \mathrm{C}$. Frozen sections $(10 \mu \mathrm{m})$ were prepared from the embedded tissue and incubated with rabbit anti-rat albumin antibody (Bethyl Laboratories, Montgomery, TX, USA) at a dilution of $1 / 100$ overnight. After washing, sections were incubated with a $1 / 200$ dilution of peroxidase-conjugated goat anti-rabbit lgG for two hours (Jackson ImmunoResearch Laboratories, West Grove, PA, USA). After thorough washing, sections were stained using the ImmPACT DAB staining kit (Vector Laboratories, Burlingame, CA, USA). Tissue sections were then mounted with Crystal Mount mounting medium (Sigma, St. Louis, MO, USA) and addition of coverslips. Staining was assessed using light microscopy (BX41, Olympus, Center Valley, PA, USA) and digital imaging (Adobe Photoshop, Adobe, San Jose, CA, USA). For each experimental condition, three animals were used. The immunostainings displayed are representative for three independent experiments.

\section{Intracerebral Evans Blue assessment}

The extent of BBB dysfunction was assessed 24 hours after induction of CLP by assessment of Evans Blue (EB) extravasation in four animals per experimental condition. Briefly, $20 \mu \mathrm{l}$ of a $2 \%$ solution of EB in saline was injected into the tail vein one hour before harvesting of brains (i.e. at $t=23$ hours after CLP), and allowed to circulate for 60 minutes. Subsequently, the chest was surgically opened under anaesthesia and the intravascular dye was removed by saline perfusion (40 to 50 $\mathrm{ml}$ ) through the left heart ventricle. The brain/pituitary was then removed and weighed before homogenisation and placed in 4 $\mathrm{mL}$ 99.5\% formamide per gram of tissue in polyethylene tubes (BD Bioscience, Rockville, MD, USA). Tubes were placed for 48 hours on a shaker (Barnstead International, Dubuque, IA, USA) at room temperature for EB extraction. Supernatants 
were collected and the absorbance read in a plate reader (Biotek Instruments, Winooski, VT, USA) at $620 \mathrm{~nm}$ and compared with an EB standard curve and formamide blanks. The result are expressed as microgram EB per milligram tissue.

\section{Isolation of total RNA and quantitative real-time PCR}

Total RNA was isolated from five to seven pituitary glands per experimental condition using the TRIzol method (Life Technologies Inc., Gaithersburg, MD, USA) according to the manufacturer's instructions. Digestion of any contaminating DNA was achieved by treatment of samples with RNase-Free DNase (Promega Corp., Madison, WI, USA). Reverse transcription was performed with $5 \mu \mathrm{g}$ RNA using the Superscript II RNase $\mathrm{H}^{-}$Reverse Transcriptase (GIBCO BRL; Life Technologies Inc., Gaithersburg, MD, USA) according to the manufacturer's protocol. Real-time PCR was then performed as previously described [13]. Reactions were prepared in duplicates using the iQ SYBR green Supermix reagent (Bio Rad Laboratories, Hercules, CA, USA). An amplification plot was generated using two-fold dilutions of the cDNA generated from a known amount $(1 \mu \mathrm{g})$ of mRNA. The cycle threshold $\left(\mathrm{C}_{\mathrm{T}}\right)$ was set above the baseline fluorescence. Plotting the log of the dilutions versus the $\mathrm{C}_{\mathrm{T}}$ values then generated a standard curve. Quantitation of samples was determined using the standard curves. Genes analysed were $\mathrm{C} 5 \mathrm{aR}$, the adrenocorticotropic hormone (ACTH)-precursor proopiomelanocortin (POMC) and growth hormone $(\mathrm{GH})$.

The following primer pairs were used:

C5aR:5' primer, 5'-TATAGTCCTGCCCTCGCTCAT-3'; 3' primer, 5'-TCACCACTTTGAGCGTCTTGG-3'.

POMC:5' primer, 5'-AGCCTCTGTCCAGTCCTGAG-3'; 3' primer, 5'-CTTAGTCACTGCTCCTTAAC-3'.

GH: 5' primer, 5'-CTCGGACCGCGTCTATGAGA-3'; and 3' primer, 5'-TGAGGATCTGCCCAATACGG-3'.

INF: 5' primer, 5'-GTGATCGGTCCCAACAAGGA-3'; and 3' primer, 5'-AGGGTCTGGGCCATGGAA-3'.

IL-6: 5' primer, 5'-ATATGTTCTCAGGGAGATCTTGGAA-3'; and 3' primer, 5'-GTGCATCATCGCTGTTCATACA-3'.

GAPDH: 5' primer, 5'-GCCTCGTCTCATAGACAAGATG-3'; and 3' primer, 5'-CAGTAGACTCCACGACATAC-3'.

\section{Western blot analysis of C5aR}

Following decapitation, rat brains were immediately removed surgically, the pituitary identified and excised, homogenised in ice-cold radio immunoprecipitation assay (RIPA) buffer (Upstate, Temecula, CA, USA) and subjected to BCA Protein Assay analysis (Thermo Scientific, Rockford, IL, USA) for equal protein loading. Total protein from pituitary lysates (50 $\mu \mathrm{g})$ was separated by electrophoresis in a denaturing $12 \%$ polyacrylamide gel and then transferred to a polyvinylidene fluoride membrane. Equal loading was confirmed by detection of glyceraldehyde 3-phosphate dehydrogenase (GAPDH) (Santa Cruz, Santa Cruz, CA, USA) as a 'housekeeping' protein. Non-specific binding sites were blocked with Tris-buffered saline Tween-20 (TBST) plus 5\% nonfat dry milk for one hour at room temperature. Following washing in TBST, the membrane was incubated with rabbit anti-rat $\mathrm{C} 5 \mathrm{aR}$ antibody (kindly provided by P.A. Ward, University of Michigan $[14,40,41])$ at a $1 / 500$ dilution overnight. After three washes in TBST, the membrane was incubated in a 1/10,000 dilution of horseradish peroxidase-conjugated donkey anti-rabbit $\lg G$ as the secondary antibody (Amersham, Piscataway, NJ, USA). The membrane was developed by enhanced chemiluminescence technique according to the manufacturer's protocol (Amersham, Piscataway, NJ, USA). Pituitary tissue was harvested from five animals and assessed by Western blotting. Due to the lane restrictions $(n=10)$ of a typical Western mini gel, two (sham groups) or three (CLP groups) samples were compared, in order to be able to evaluate samples directly 'side-by-side'. The blot depicted is representative of three independent experiments.

\section{ELISA of pituitary hormone levels}

Rat whole blood was collected into syringes containing anticoagulant citrate dextrose (Baxter, Deerfield, IL, USA) in a 9:1 ratio by puncture of the inferior vena cava 24 hours after CLP or sham surgery. Samples were centrifuged $(2500 \mathrm{rpm}$ for 10 minutes at $4^{\circ} \mathrm{C}$ ), plasma was obtained and immediately stored at $-80^{\circ} \mathrm{C}$. Levels of $\mathrm{GH}$ and corticosterone were determined using commercially available ELISA kits (both Diagnostic Systems Laboratories, Webster, TX, USA) according to the manufacturer's instructions. For plasma measurements of $\mathrm{GH}$ and corticosterone, five to seven samples were assessed for each experimental group.

\section{Statistical analysis}

All values are expressed as mean \pm standard deviation. Data were analysed with a one-way analysis of variance, and individual group means were then compared with the Tukey multiple comparison test. Differences were considered statistically significant at $\mathrm{p}<0.05$.

\section{Results \\ Anti-C5a prevents BBB breakdown during experimental sepsis}

As depicted in Figure 1, as a negative control, primary antibody was omitted in a section obtained from a preimmune lgG-treated animal (panel a) and little straining of brain tissue for albumin was noted. Sham animals treated with either preimmune lgG (panel b) or anti-C5a (panel c) displayed comparable levels of baseline immunostaining for albumin. However, there was a significant increase in diffuse cerebral albumin accumulation 24 hours after CLP in animals treated with pre- 
Figure 1

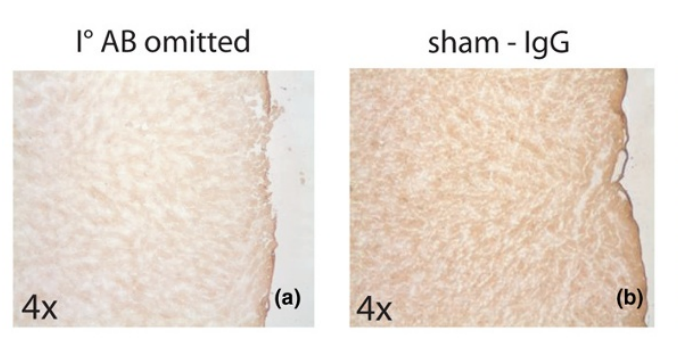

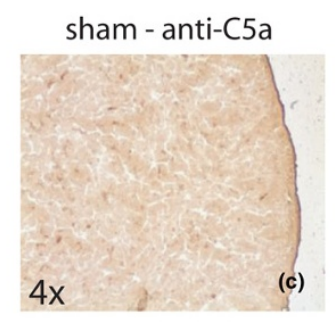

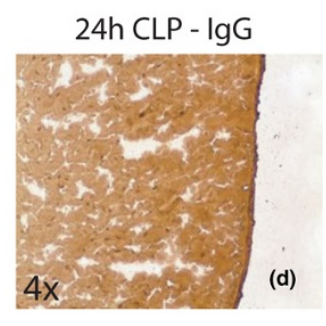

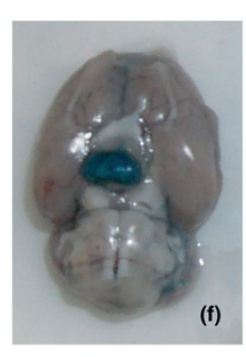

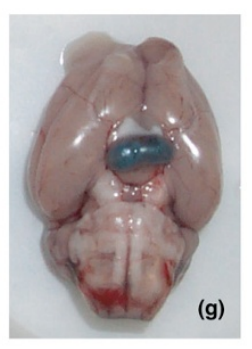

$24 h$ CLP - IgG

24h CLP - anti-C5a
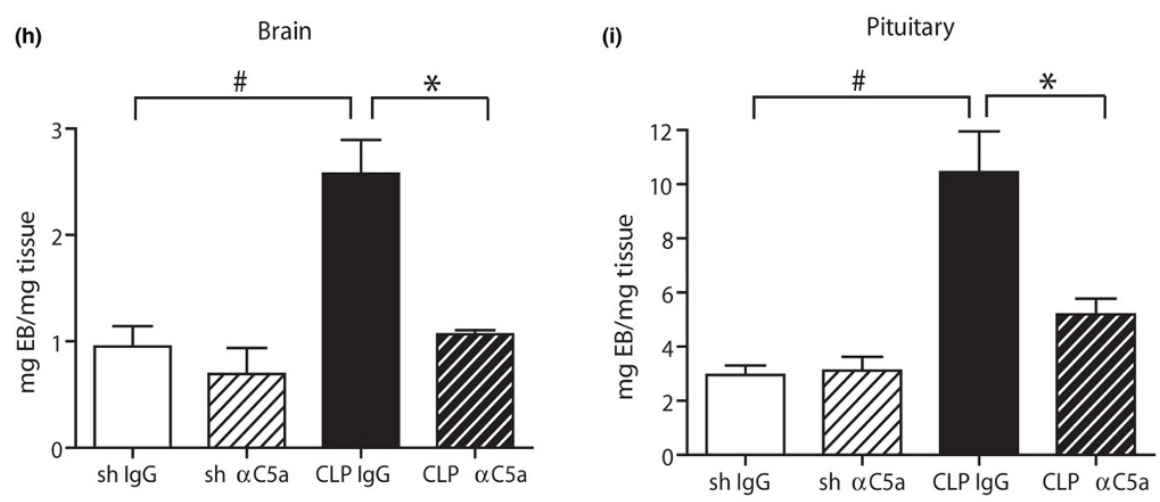

Anti-C5a ameliorates impairment of the blood-brain barrier after caecal ligation and puncture (CLP). (a-e) Brains were surgically removed, snap-frozen and tissue sections $(10 \mu \mathrm{m})$ were obtained. Cerebral extravasation of rat albumin was assessed by immunohistochemistry 24 hours after CLP or sham procedure, three samples per experimental condition. Stains displayed are representative of three independent experiments. (f, $\mathbf{g}$ ) Comparison of Evans Blue extravasation into the cerebellum and pituitary in IgG-treated or anti-C5a treated rats 24 hours post CLP. Displayed depictions are representative of four animals. (h, i) Quantification of Evans Blue extravasation into the brain or pituitary by determination of $\mathrm{mg}$ Evans Blue/mg tissue ratio in different groups at indicated time-points, four for each experimental condition. \# $p<0.05$ between sham and 24 hours CLP animals; * $p$ $<0.05$ between IgG-treated and anti-C5a-treated rats.

immune IgG (panel d). In contrast, when rats received antiC5a immediately after the CLP procedure, cerebral albumin build-up was dramatically reduced to sham levels (panels $b$ and e).

Similar results were found when breakdown of the BBB was analysed by EB extravasation 24 hours after CLP. Animals treated with preimmune lgG displayed robust EB extravasation in the cerebral and pituitary areas (panel f), while anti-C5atreated littermates exhibited far less buildup of EB (panel $\mathrm{g}$ ). Panels $h$ and i show quantified EB extravasation 24 hours after $\mathrm{CLP}$ as $\mathrm{mg} \mathrm{EB/mg} \mathrm{tissue} \mathrm{ratio} \mathrm{and} \mathrm{confirm} \mathrm{the} \mathrm{observations}$ made in panels $f$ and $g$ on a quantitative level.

\section{C5aR is upregulated in the pituitary gland of septic rats}

Rat pituitary glands were surgically removed, total RNA was isolated and analysed by quantitative real-time PCR. There was a significant increase of pituitary C5aR expression 24 hours after CLP in animals receiving preimmune $\mathrm{IgG}$, while anti-C5a-treated littermates displayed expression levels comparable with sham animals (Figure 2a). Similar results were found when pituitaries were homogenised and obtained pro- teins were subjected to Western blot analysis. Protein expression of $\mathrm{C} 5 \mathrm{aR}$ in the pituitary was markedly increased in IgGtreated animals 24 hours after CLP, while rats that were administered anti-C5a revealed $\mathrm{C} 5 \mathrm{aR}$ protein expression similar to sham controls (Figure 2b). Such patterns of increased C5aR expression in CLP mice have been described in lung, liver, kidney and heart [12].

\section{C5a-blockade partially reverses cytokine upregulation in the pituitary gland}

Following isolation of pituitary total RNA, quantitative real-time PCR was performed for TNF and IL-6. Sham animals treated with either preimmune $\lg \mathrm{G}$ or anti-C5a displayed similar expression of mRNA for both proinflammatory mediators. However, 24 hours after the CLP procedure, mRNA expression for TNF and IL-6 was substantially increased in IgGtreated rats (Figure 3 ). Elevated mRNA levels were partially reduced to sham levels when animals were administered antiC5a immediately after CLP. 
Figure 2

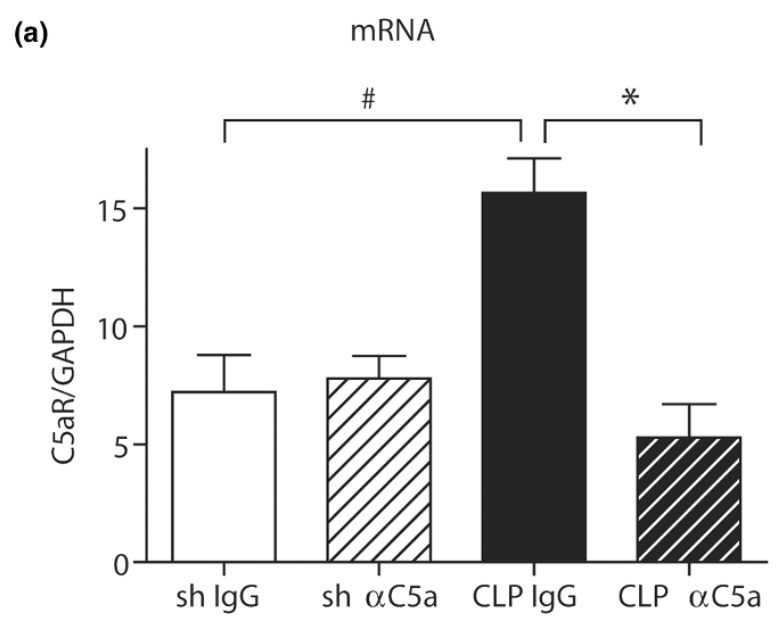

(b)

Protein

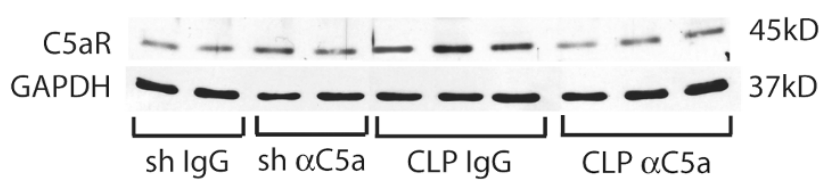

Pituitary expression of $\mathrm{C} 5$ a receptor $(\mathrm{R})$ during experimental sepsis in IgG or anti-C5a lgG treated sham animals and septic littermates 24 hours after caecal ligation and puncture (CLP) procedure. (a) Following total RNA isolation from pituitary tissue, pituitary C5aR mRNA expression was assessed by real-time PCR. For each bar, sample size was five to seven. (b) Five pituitary tissue samples were removed at indicated time-points, homogenised and C5aR protein expression was analysed by Western blotting. For sham groups, two samples were taken; for CLP groups, three samples were taken. Blot is representative for three independent experiments. GAPDH = glyceraldehyde 3-phosphate dehydrogenase. \# $p<0.05$ between sham and 24 hours CLP animals; * $p<0.05$ between IgG-treated and anti-C5a-treated rats.

\section{Pituitary dysfunction is reversed by C5a blockade}

Pituitary glands were surgically removed, total RNA was isolated and analysed for $\mathrm{POMC}$ and $\mathrm{GH}$ by quantitative real-time PCR. mRNA expression for both, POMC and GH was dramatically reduced 24 hours after CLP in IgG-treated rats (Figures $4 a, b)$. Anti-C5a administration completely reversed these changes, resulting in POMC and GH mRNA expression levels equivalent to sham groups. Plasma samples were obtained 24 hours after CLP or sham procedure and subjected to ELISA analysis for $\mathrm{GH}$ and corticosterone, the main glucocorticoid of rodents. When compared with sham animals, IgG-treated rats had with significantly increased plasma levels of $\mathrm{GH}$ and corticosterone 24 hours after CLP. Again, these changes were reversed by administration of anti-C5a immediately after CLP (Figures 4c,d).

\section{Discussion}

Under physiological conditions, the BBB maintains the cerebral micro-environment by tightly regulating the passage of molecules into and out of the brain to protect the brain from microorganisms and neurotoxic substances. During sepsis, however, blood-borne proinflammatory mediators are released, coincidental with diffuse endothelial activation and subsequent upregulation of vascular adhesion molecule-1 (VCAM-1), intracellular adhesion molecule-1 (ICAM-1), Eselectin on cerebral endothelia [42-45], facilitating adhesion and transmigration of neutrophils and monocytes into the brain tissue. Especially the anaphylatoxin $\mathrm{C} 5 \mathrm{a}$ is known to be a strong inducer of ICAM-1, VCAM-1 and various selectins [4650]. In addition, cerebral endothelia produce IL-1 $\beta$, TNF and IL-6 [51-53], all of which have been shown to directly induce a disruption of the BBB in vitro [54]. Thus, these mediators interact with surrounding brain cells, relaying into the brain inflammatory response and jeopardising the functional integrity of the BBB [55-57]. In the present study, we found that, during experimental sepsis, the antibody-mediated blockade of anaphylatoxin C5a prevented breakdown of the blood-brain barrier, reducing cerebral and pituitary edema formation, as assessed by extravasation of albumin and EB (Figure 1).

Although the CNS itself was traditionally thought to be immunologically privileged, recent studies have demonstrated that the CNS is a rich source of inflammatory mediators, such as cytokines, chemokines and complement components [58-64], and has therefore been termed both 'culprit' and 'victim' during sepsis [57]. Thus, during sepsis, the BBB is exposed to harmful proinflammatory mediators deriving from two different compartments, the brain as well as the systemic circulation. This results in an extrinsic, as well as intrinsic, attack on the BBB, accelerating the deterioration of its barrier function. As described above, we demonstrate significant upregulation of pituitary expression of TNF and IL-6 mRNA following CLP (Figure 3 ), indicating that the pituitary might be an additional source of cerebral proinflammatory mediators. Blood-derived proinflammatory mediators reach the hypophyseal circulation via the anterior hypophyseal arteries and cytokines can diffuse into the pituitary because these areas are free from CNS BBB [65]. Therefore, we decided that mRNA analysis for TNF and IL-6 might shed a more accurate light on the origin of these proinflammatory mediators.

Resident cells of the brain, such as neurons, astrocytes and microglia, are capable of synthesising essentially all complement proteins, complement regulatory molecules and complement receptors $[31,66-70]$. It has been reported that the pituitary expresses the complement receptors C3aR, C5aR and $\mathrm{C} 5 a-$-like receptor 2 (C5L2), and that these molecules may contribute to regulation of the immune response $[71,72]$. We found upregulation of $\mathrm{C} 5 \mathrm{aR}$ in the pituitary based on mRNA and protein levels following CLP and reversal of these changes by administration of anti-C5a (Figure 2). Upregulation 
(a)

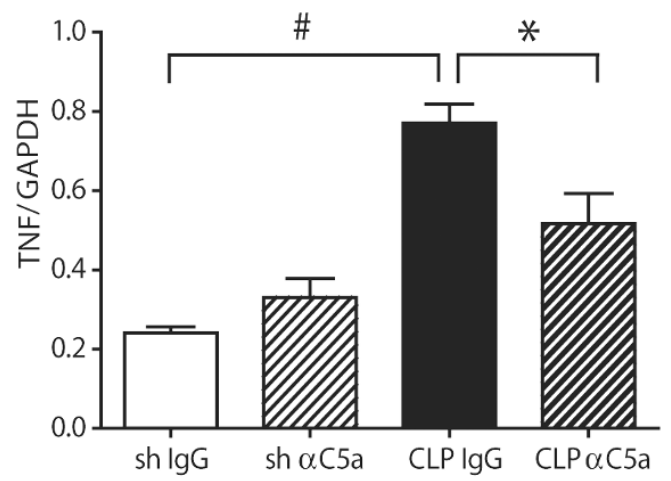

(b) mRNA

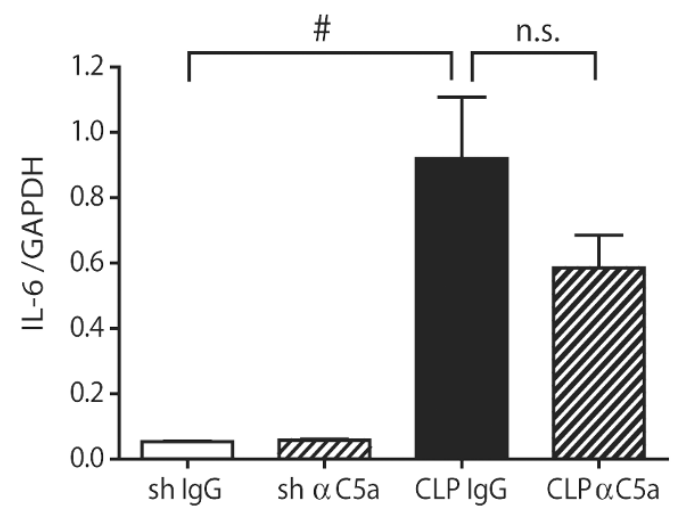

Expression of inflammatory mediators in the pituitary. Pituitary tissue samples were surgically removed, snap-frozen, homogenised and total RNA was extracted. Samples were then analysed by quantitative real-time PCR analysis. Expression of (a) TNF and (b) IL-6 mRNA in the pituitary 24 hours after sham procedure or caecal ligation and puncture (CLP). Five to seven samples were taken per experimental condition. GAPDH $=$ glyceraldehyde 3-phosphate dehydrogenase. \# $p<0.05$ between sham and 24 hours CLP animals; ${ }^{*} p<0.05$ between lgG-treated and anti-C5a-treated rats.

of $\mathrm{C} 5 \mathrm{aR}$ during sepsis has been described in various organs, such as lung, liver, kidney and heart [12]. Such upregulation infers that these tissues may develop highly undesirable outcomes after encounters with C5a.

Sepsis is known to induce an abnormal pituitary response [73]. Hormonal changes in cortisol, mineralocorticoids, thyroid hormones, $\mathrm{GH}$ and vasopressin have all been described during sepsis. Although the acute phase of sepsis is characterised by high levels of $\mathrm{GH}, \mathrm{GH}$ insufficiency is reported in the late stage of sepsis $[73,74]$. In line with these findings, we have found elevated levels of $\mathrm{GH}$ protein 24 hours after CLP, while pituitary mRNA expression is significantly reduced, most likely because of a negative feedback mechanism.

Hypercortisolism during the early stages of sepsis is usually followed by cortisol insufficiency in $60 \%$ of septic patients [73]. Significantly increased levels of corticosterone occurred in rats following CLP (Figure 4). In the current study, pituitary POMC mRNA expression was completely abolished during experimental sepsis (Figure 4). POMC is a polypeptide precursor of multiple molecules, including ACTH and melanocytestimulating hormones (MSH) $\alpha, \beta$ and $\gamma$ [75]. Interestingly, $\mathrm{MSH}-\alpha$ has recently emerged as a molecule with potent antiinflammatory effects, which orchestrates descending neurogenic anti-inflammatory pathways and ameliorates the inflammatory response of immune cells [76]. At a molecular level, MSH- $\alpha$ decreases the intracellular production of proinflammatory cytokines and chemokines by inhibiting nuclear factor- $\mathrm{B}$ B activation and reduces cellular expression of VCAM1, ICAM-1 and E-selectin [76]. During human sepsis, plasma concentrations of $\mathrm{MSH}-\alpha$ have been found to be significantly decreased during the early course of the disease and gradu- ally recovered as a function of time [77]. More importantly, its concentrations negatively correlated with plasma concentrations of TNF and IL-1 $\beta$ [77]. Thus, it is tempting to speculate, whether the observed pituitary upregulation of TNF and IL-6 mRNA (Figure 3 ) is related to the complete absence of POMC expression (Figure 4), which will result in a lack of pituitary $\mathrm{MSH}-\alpha$ production with uninhibited proinflammatory activation of pituitary cells.

It remains to be determined if our findings can be extrapolated into humans. Several reports have stressed the disconnection between rodent and human sepsis [78-80], making it difficult to draw definitive conclusions from an experimental study for the clinical setting. Moreover, in the current study, the C5aneutralising antibody was administered immediately after the CLP procedure. Follow-up studies need to address the effects of delayed anti-C5a treatment, because diagnosis of the sepsis syndrome in patients might be delayed due to several comorbidities. Thus, it is imperative to address if anti-C5a treatment also reverses BBB and pituitary dysfunction after onset of CLP, which would greatly enhance the therapeutic impact of a potential C5a-blockade in humans.

\section{Conclusions}

We describe amelioration of BBB breakdown and partial reversal of pituitary dysfunction by neutralisation of C5a during experimental sepsis. Similarly, blockade of C5aR has recently been described to reduce the LPS-induced activation in the paraventricular nucleus and the central amygdala [81]. Thus, as we are beginning to gain novel insights into the crucial role of $\mathrm{C} 5 \mathrm{a}$ in the development of sepsis-induced BBB dysfunction, we might be able to immunomodulate its detrimental effects and improve the outcome of septic encephalopathy. 
(a)

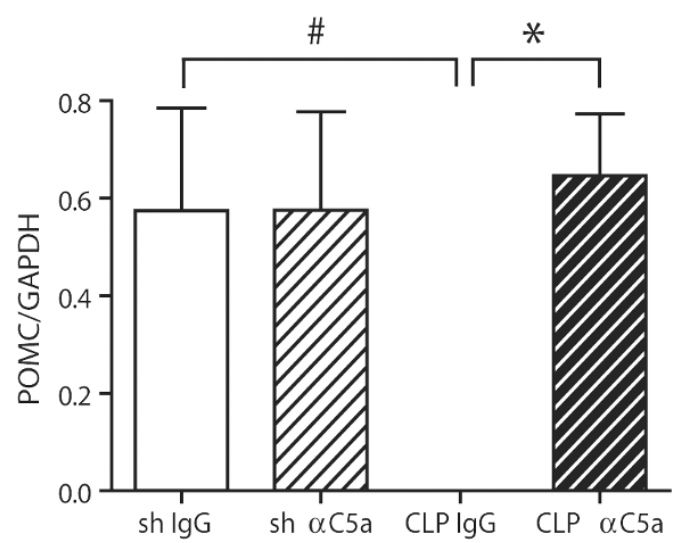

(c)

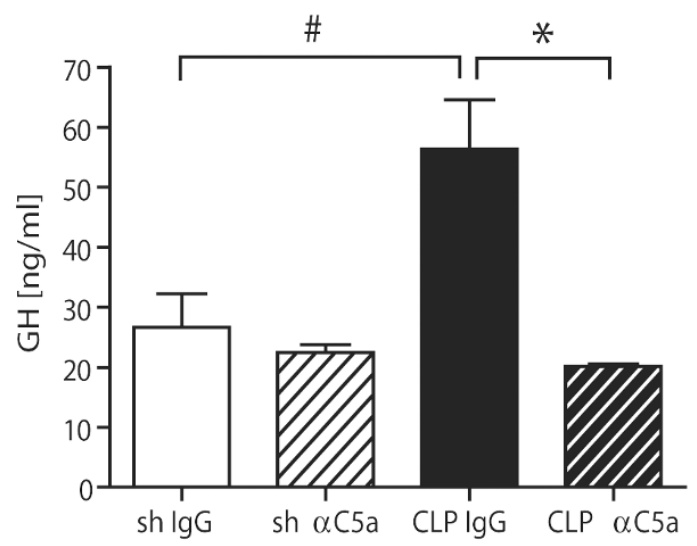

(b)

mRNA

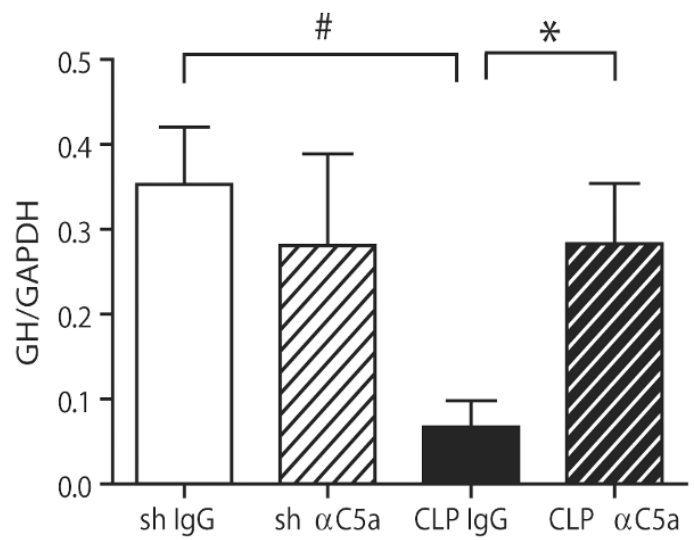

(d)

Plasma

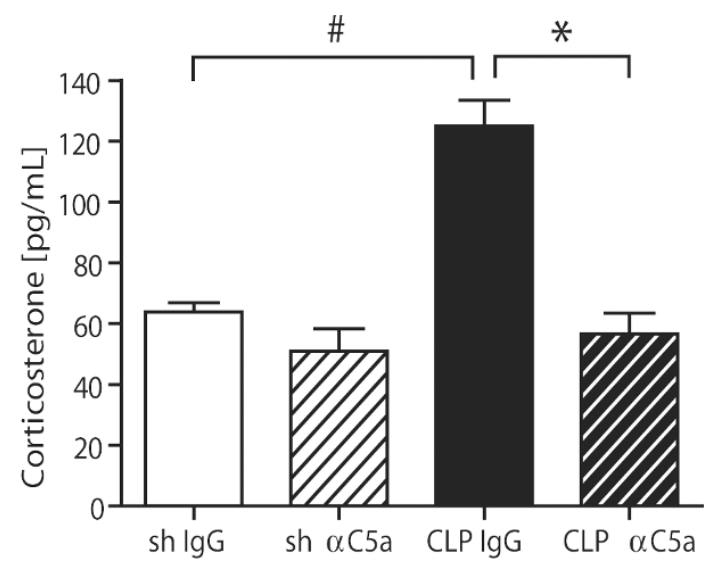

Evaluation of pituitary function after caecal ligation and puncture (CLP). Pituitary tissue samples were removed from four to five mice, snap-frozen, homogenised in Trizol and total RNA was extracted. Assessment of mRNA expression of (a) proopiomelanocortin (POMC) and (b) growth hormone (GH) 24 hours after CLP or sham operation by real-time PCR. Whole blood samples were drawn at given time-points by puncture of the inferior vena cava, plasma was obtained by centrifugation and subjected to ELISA analysis. Samples were assessed for (c) GH or (d) corticosterone under identical conditions. For all graphs, there were five to seven samples per experimental condition. GAPDH = glyceraldehyde 3-phosphate dehydrogenase. $\# p<0.05$ between sham and 24 hours CLP animals; * $p<0.05$ between IgG-treated and anti-C5a-treated rats.

\section{Key messages}

- Anti-C5a prevents break-down of the BBB during experimental sepsis.

- The C5aR is robustly upregulated in the pituitary gland during CLP-induced sepsis.

- Pituitary mRNA expression of proinflammatory TNF and IL-6 is upregulated during experimental sepsis.

- Experimental sepsis induces pituitary dysfunction which is ameliorated by a neutralising anti-C5a antibody.

\section{Competing interests}

The authors declare that they have no competing interests.

\section{Authors' contributions}

MAF, PFS, MHL, PAW and KI designed the study and supervised the experiments. MAF, DR, AND, LMH and BMT performed the experiments. MAF, PFS, SJM, WRS and KI analysed the data and drafted the manuscript. All authors revised the manuscript for important scientific content, read and approved the final manuscript. 


\section{References}

1. Dombrovskiy VY, Martin AA, Sunderram J, Paz HL: Rapid increase in hospitalization and mortality rates for severe sepsis in the United States: a trend analysis from 1993 to 2003. Crit Care Med 2007, 35:1244-1250.

2. Kung HC, Hoyert DL, Xu J, Murphy SL: Deaths: final data for 2005. Natl Vital Stat Rep 2008, 56:1-120.

3. Rittirsch D, Flierl MA, Ward PA: Harmful molecular mechanisms in sepsis. Nat Rev Immunol 2008, 8:776-787.

4. Levy MM, Fink MP, Marshall JC, Abraham E, Angus D, Cook D, Cohen J, Opal SM, Vincent JL, Ramsay G: 2001 SCCM/ESICM/ ACCP/ATS/SIS International Sepsis Definitions Conference. Crit Care Med 2003, 31:1250-1256.

5. Annane D, Bellissant E, Cavaillon JM: Septic shock. Lancet 2005, 365:63-78

6. Nakae H, Endo S, Inada K, Takakuwa T, Kasai T, Yoshida M: Serum complement levels and severity of sepsis. Res Commun Chem Pathol Pharmacol 1994, 84:189-195.

7. Nakae H, Endo S, Inada K, Yoshida M: Chronological changes in the complement system in sepsis. Surg Today 1996, 26:225-229.

8. Stove S, Welte T, Wagner TO, Kola A, Klos A, Bautsch W, Kohl J: Circulating complement proteins in patients with sepsis or systemic inflammatory response syndrome. Clin Diagn Lab Immunol 1996, 3:175-183.

9. Hack CE, Nuijens JH, Felt-Bersma RJ, Schreuder WO, EerenbergBelmer AJ, Paardekooper J, Bronsveld W, Thijs LG: Elevated plasma levels of the anaphylatoxins $\mathrm{C} 3 \mathrm{a}$ and $\mathrm{C} 4 \mathrm{a}$ are associated with a fatal outcome in sepsis. Am J Med 1989, 86:20-26.

10. Czermak BJ, Sarma V, Pierson CL, Warner RL, Huber-Lang M, Bless NM, Schmal H, Friedl HP, Ward PA: Protective effects of C5a blockade in sepsis. Nat Med 1999, 5:788-792.

11. Huber-Lang MS, Sarma JV, McGuire SR, Lu KT, Guo RF, Padgaonkar VA, Younkin EM, Laudes IJ, Riedemann NC, Younger JG, Ward PA: Protective effects of anti-C5a peptide antibodies in experimental sepsis. Faseb J 2001, 15:568-570.

12. Riedemann NC, Guo RF, Neff TA, Laudes IJ, Keller KA, Sarma VJ, Markiewski MM, Mastellos D, Strey CW, Pierson CL, Lambris JD, Zetoune FS, Ward PA: Increased C5a receptor expression in sepsis. J Clin Invest 2002, 110:101-108.

13. Niederbichler AD, Hoesel LM, Westfall MV, Gao H, Ipaktchi KR, Sun L, Zetoune FS, Su GL, Arbabi S, Sarma JV, Wang SC, Hemmila MR, Ward PA: An essential role for complement C5a in the pathogenesis of septic cardiac dysfunction. J Exp Med 2006, 203:53-61.

14. Rittirsch D, Flierl MA, Nadeau BA, Day DE, Huber-Lang M, Mackay CR, Zetoune FS, Gerard NP, Cianflone K, Kohl J, Gerard C, Sarma JV, Ward PA: Functional roles for $\mathrm{C5a}$ receptors in sepsis. Nat Med 2008, 14:551-557.

15. Gerard C: Complement C5a in the sepsis syndrome - too much of a good thing? $N$ Engl J Med 2003, 348:167-169.

16. Ward PA: The dark side of C5a in sepsis. Nat Rev Immunol 2004, 4:133-142.

17. Guo RF, Huber-Lang $M$, Wang $X$, Sarma V, Padgaonkar VA, Craig RA, Riedemann NC, McClintock SD, Hlaing T, Shi MM, Ward PA: Protective effects of anti-C5a in sepsis-induced thymocyte apoptosis. J Clin Invest 2000, 106:1271-1280.

18. Flierl MA, Rittirsch D, Chen AJ, Nadeau BA, Day DE, Sarma JV, Huber-Lang MS, Ward PA: The complement anaphylatoxin C5a induces apoptosis in adrenomedullary cells during experimental sepsis. PLoS ONE 2008, 3:e2560.

19. Huber-Lang MS, Riedeman NC, Sarma JV, Younkin EM, McGuire SR, Laudes IJ, Lu KT, Guo RF, Neff TA, Padgaonkar VA, Lambris JD, Spruce L, Mastellos D, Zetoune FS, Ward PA: Protection of innate immunity by C5aR antagonist in septic mice. Faseb J 2002, 16:1567-1574.

20. Huber-Lang MS, Younkin EM, Sarma JV, McGuire SR, Lu KT, Guo RF, Padgaonkar VA, Curnutte JT, Erickson R, Ward PA: Complement-induced impairment of innate immunity during sepsis. $J$ Immunol 2002, 169:3223-3231.

21. Laudes IJ, Chu JC, Sikranth S, Huber-Lang M, Guo RF, Riedemann $\mathrm{N}$, Sarma JV, Schmaier AH, Ward PA: Anti-c5a ameliorates coagulation/fibrinolytic protein changes in a rat model of sepsis. Am J Pathol 2002, 160:1867-1875

22. Huber-Lang M, Sarma VJ, Lu KT, McGuire SR, Padgaonkar VA, Guo RF, Younkin EM, Kunkel RG, Ding J, Erickson R, Curnutte JT,
Ward PA: Role of C5a in multiorgan failure during sepsis. $J$ Immunol 2001, 166:1193-1199.

23. Semmler A, Hermann S, Mormann F, Weberpals M, Paxian SA, Okulla T, Schafers M, Kummer MP, Klockgether T, Heneka MT: Sepsis causes neuroinflammation and concomitant decrease of cerebral metabolism. J Neuroinflammation 2008, 5:38.

24. Piazza O, Russo E, Cotena S, Esposito G, Tufano R: Elevated S100B levels do not correlate with the severity of encephalopathy during sepsis. $\mathrm{Br} J$ Anaesth 2007, 99:518-521.

25. Alexander JJ, Jacob A, Cunningham P, Hensley L, Quigg RJ: TNF is a key mediator of septic encephalopathy acting through its receptor, TNF receptor-1. Neurochem Int 2008, 52:447-456.

26. Wratten ML: Therapeutic approaches to reduce systemic inflammation in septic-associated neurologic complications. Eur J Anaesthesiol Supp/ 2008, 42:1-7.

27. Handa O, Stephen J, Cepinskas G: Role of eNOS-derived nitric oxide (NO) in activation and dysfunction of cerebrovascular endothelial cells during early onsets of sepsis. $A m J$ Physiol Heart Circ Physiol 2008, 295:H1712-1719.

28. Toklu HZ, Uysal MK, Kabasakal L, Sirvanci S, Ercan F, Kaya M: The effects of riluzole on neurological, brain biochemical, and histological changes in early and late term of sepsis in rats. Surg Res 2008.

29. Hofer S, Bopp C, Hoerner C, Plaschke K, Faden RM, Martin E Bardenheuer HJ, Weigand MA: Injury of the blood brain barrier and up-regulation of icam-1 in polymicrobial sepsis. J Surg Res 2008, 146:276-281.

30. Faustmann PM, Krause D, Dux R, Dermietzel R: Morphological study in the early stages of complement C5a fragmentinduced experimental meningitis: activation of macrophages and astrocytes. Acta Neuropathol 1995, 89:239-247.

31. Nataf S, Stahel PF, Davoust N, Barnum SR: Complement anaphylatoxin receptors on neurons: new tricks for old receptors? Trends Neurosci 1999, 22:397-402.

32. Stahel PF, Barnum SR: The role of the complement system in CNS inflammatory diseases. Expert Rev Clin Immunol 2006, 2:445-456.

33. Stahel PF, Frei K, Eugster HP, Fontana A, Hummel KM, Wetsel RA, Ames RS, Barnum SR: TNF-alpha-mediated expression of the receptor for anaphylatoxin $\mathrm{C} 5 \mathrm{a}$ on neurons in experimental Listeria meningoencephalitis. J Immunol 1997, 159:861-869.

34. Osaka H, McGinty A, Hoepken UE, Lu B, Gerard C, Pasinetti GM: Expression of $\mathrm{C5a}$ receptor in mouse brain: role in signal transduction and neurodegeneration. Neuroscience 1999 , 88:1073-1082.

35. O'Barr SA, Caguioa J, Gruol D, Perkins G, Ember JA, Hugli T, Cooper NR: Neuronal expression of a functional receptor for the C5a complement activation fragment. J Immunol 2001 166:4154-4162.

36. Ernst JD, Hartiala KT, Goldstein IM, Sande MA: Complement (C5)-derived chemotactic activity accounts for accumulation of polymorphonuclear leukocytes in cerebrospinal fluid of rabbits with pneumococcal meningitis. Infect Immun 1984, 46:81-86.

37. Williams CA, Schupf N, Hugli TE: Anaphylatoxin C5a modulation of an alpha-adrenergic receptor system in the rat hypothalamus. J Neuroimmunol 1985, 9:29-40.

38. Jacob A, Hensley LK, Safratowich BD, Quigg RJ, Alexander JJ: The role of the complement cascade in endotoxin-induced septic encephalopathy. Lab Invest 2007, 87:1186-1194.

39. Baker CC, Chaudry IH, Gaines HO, Baue AE: Evaluation of factors affecting mortality rate after sepsis in a murine cecal ligation and puncture model. Surgery 1983, 94:331-335.

40. Laudes IJ, Chu JC, Huber-Lang M, Guo RF, Riedemann NC, Sarma JV, Mahdi F, Murphy HS, Speyer C, Lu KT, Lambris JD, Zetoune $\mathrm{FS}$, Ward PA: Expression and function of $\mathrm{C} 5 \mathrm{a}$ receptor in mouse microvascular endothelial cells. J Immunol 2002, 169:5962-5970.

41. Riedemann NC, Neff TA, Guo RF, Bernacki KD, Laudes IJ, Sarma JV, Lambris JD, Ward PA: Protective effects of IL-6 blockade in sepsis are linked to reduced $\mathrm{C} 5$ a receptor expression. J Immunol 2003, 170:503-507.

42. Wong D, Dorovini-Zis K: Expression of vascular cell adhesion molecule-1 (VCAM-1) by human brain microvessel endothelial cells in primary culture. Microvasc Res 1995, 49:325-339. 
43. Hess DC, Thompson Y, Sprinkle A, Carroll J, Smith J: E-selectin expression on human brain microvascular endothelial cells. Neurosci Lett 1996, 213:37-40.

44. Hess DC, Bhutwala T, Sheppard JC, Zhao W, Smith J: ICAM-1 expression on human brain microvascular endothelial cells. Neurosci Lett 1994, 168:201-204.

45. Rieckmann P, Michel U, Albrecht M, Bruck W, Wockel L, Felgenhauer K: Cerebral endothelial cells are a major source for soluble intercellular adhesion molecule-1 in the human central nervous system. Neurosci Lett 1995, 186:61-64.

46. Mulligan MS, Schmid E, Till GO, Hugli TE, Friedl HP, Roth RA, Ward PA: C5a-dependent up-regulation in vivo of lung vascular P-selectin. J Immunol 1997, 158:1857-1861.

47. Foreman $\mathrm{KE}$, Vaporciyan $\mathrm{AA}$, Bonish $\mathrm{BK}$, Jones $\mathrm{ML}$, Johnson $\mathrm{KJ}$, Glovsky MM, Eddy SM, Ward PA: C5a-induced expression of Pselectin in endothelial cells. J Clin Invest 1994, 94:1147-1155.

48. Albrecht EA, Chinnaiyan AM, Varambally S, Kumar-Sinha C, Barrette TR, Sarma JV, Ward PA: C5a-induced gene expression in human umbilical vein endothelial cells. Am J Pathol 2004, 164:849-859.

49. Mulligan MS, Schmid E Beck-Schimmer B, Till GO, Friedl HP Brauer RB, Hugli TE, Miyasaka M, Warner RL, Johnson KJ, Ward PA: Requirement and role of $\mathrm{C5a}$ in acute lung inflammatory injury in rats. J Clin Invest 1996, 98:503-512.

50. Schmid E, Piccolo MT, Friedl HP, Warner RL, Mulligan MS, Hugli TE, Till GO, Ward PA: Requirement for C5a in lung vascular injury following thermal trauma to rat skin. Shock 1997, 8:119-124.

51. Breder CD, Hazuka C, Ghayur T, Klug C, Huginin M, Yasuda K, Teng M, Saper CB: Regional induction of tumor necrosis factor alpha expression in the mouse brain after systemic lipopolysaccharide administration. Proc Natl Acad Sci USA 1994, 91:11393-11397.

52. Fabry Z, Fitzsimmons KM, Herlein JA, Moninger TO, Dobbs MB, Hart MN: Production of the cytokines interleukin 1 and 6 by murine brain microvessel endothelium and smooth muscle pericytes. J Neuroimmunol 1993, 47:23-34.

53. Reyes TM, Fabry Z, Coe CL: Brain endothelial cell production of a neuroprotective cytokine, interleukin-6, in response to noxious stimuli. Brain Res 1999, 851:215-220.

54. de Vries HE, Blom-Roosemalen MC, van Oosten M, de Boer AG, van Berkel TJ, Breimer DD, Kuiper J: The influence of cytokines on the integrity of the blood-brain barrier in vitro. J Neuroimmunol 1996, 64:37-43.

55. Papadopoulos MC, Davies DC, Moss RF, Tighe D, Bennett ED: Pathophysiology of septic encephalopathy: a review. Crit Care Med 2000, 28:3019-3024.

56. Sharshar T, Carlier R, Bernard F, Guidoux C, Brouland JP, Nardi O, de la Grandmaison GL, Aboab J, Gray F, Menon D, Annane D: Brain lesions in septic shock: a magnetic resonance imaging study. Intensive Care Med 2007, 33:798-806.

57. Sharshar T, Hopkinson NS, Orlikowski D, Annane D: Science review: The brain in sepsis - culprit and victim. Crit Care 2005, 9:37-44.

58. Hanisch UK: Microglia as a source and target of cytokines. Glia 2002, 40:140-155.

59. Ghirnikar RS, Lee YL, Eng LF: Inflammation in traumatic brain injury: role of cytokines and chemokines. Neurochem Res 1998, 23:329-340.

60. Ransohoff RM, Tani M: Do chemokines mediate leukocyte recruitment in post-traumatic CNS inflammation? Trends Neurosci 1998, 21:154-159.

61. Stahel PF, Kariya K, Shohami E, Barnum SR, Eugster H, Trentz O, Kossmann T, Morganti-Kossmann MC: Intracerebral complement C5a receptor (CD88) expression is regulated by TNF and lymphotoxin-alpha following closed head injury in mice. $J$ Neuroimmunol 2000, 109:164-172.

62. Gasque P, Dean YD, McGreal EP, VanBeek J, Morgan BP: Complement components of the innate immune system in health and disease in the CNS. Immunopharmacology 2000, 49:171-186.

63. Boos L, Campbell IL, Ames R, Wetsel RA, Barnum SR: Deletion of the complement anaphylatoxin $\mathrm{C} 3 \mathrm{a}$ receptor attenuates, whereas ectopic expression of $\mathrm{C} 3 \mathrm{a}$ in the brain exacerbates, experimental autoimmune encephalomyelitis. J Immunol 2004, 173:4708-4714.
64. Lynch NJ, Willis CL, Nolan CC, Roscher S, Fowler MJ, Weihe E, Ray DE, Schwaeble WJ: Microglial activation and increased synthesis of complement component $\mathrm{C} 1 \mathrm{q}$ precedes bloodbrain barrier dysfunction in rats. Mol Immunol 2004, 40:709-716.

65. Porter JC, Sissom JF, Arita J, Reymond MJ: Hypothalamic-hypophysial vasculature and its relationship to secretory cells of the hypothalamus and pituitary gland. Vitam Horm 1983 40:145-174.

66. Rancan M, Morganti-Kossmann MC, Barnum SR, Saft S, Schmidt Ol, Ertel W, Stahel PF: Central nervous system-targeted complement inhibition mediates neuroprotection after closed head injury in transgenic mice. J Cereb Blood Flow Metab 2003, 23:1070-1074.

67. Stahel PF, Kossmann T, Morganti-Kossmann MC, Hans VH, Barnum SR: Experimental diffuse axonal injury induces enhanced neuronal C5a receptor mRNA expression in rats. Brain Res Mol Brain Res 1997, 50:205-212.

68. Gasque P, Singhrao SK, Neal JW, Gotze O, Morgan BP: Expression of the receptor for complement C5a (CD88) is up-regulated on reactive astrocytes, microglia, and endothelial cells in the inflamed human central nervous system. Am J Pathol 1997, 150:31-41.

69. Francis K, van Beek J, Canova C, Neal JW, Gasque P: Innate immunity and brain inflammation: the key role of complement. Expert Rev Mol Med 2003, 5:1-19.

70. Davoust N, Jones J, Stahel PF, Ames RS, Barnum SR: Receptor for the $\mathrm{C} 3 \mathrm{a}$ anaphylatoxin is expressed by neurons and glial cells. Glia 1999, 26:201-211.

71. Francis K, Lewis BM, Akatsu H, Monk PN, Cain SA, Scanlon MF, Morgan BP, Ham J, Gasque P: Complement C3a receptors in the pituitary gland: a novel pathway by which an innate immune molecule releases hormones involved in the control of inflammation. Faseb J 2003, 17:2266-2268.

72. Lewis BM, Francis K, Monk P, Scanlon MF, Ham J: Complement C5a inhibits the secretion of macrophage migration inhibitory factor in anterior pituitary cell lines. Endocrine Abstracts 2006 11:P602.

73. Maxime V, Siami S, Annane D: Metabolism modulators in sepsis: the abnormal pituitary response. Crit Care Med 2007, 35:S596-601.

74. Ross R, Miell J, Freeman E, Jones J, Matthews D, Preece M, Buchanan C: Critically ill patients have high basal growth hormone levels with attenuated oscillatory activity associated with low levels of insulin-like growth factor-I. Clin Endocrinol (Oxf) 1991, 35:47-54

75. Raffin-Sanson ML, de Keyzer Y, Bertagna X: Proopiomelanocortin, a polypeptide precursor with multiple functions: from physiology to pathological conditions. Eur J Endocrinol 2003 149:79-90.

76. Brzoska T, Luger TA, Maaser C, Abels C, Bohm M: Alphamelanocyte-stimulating hormone and related tripeptides: biochemistry, antiinflammatory and protective effects in vitro and in vivo, and future perspectives for the treatment of immunemediated inflammatory diseases. Endocr Rev 2008, 29:581-602.

77. Catania A, Cutuli M, Garofalo L, Airaghi L, Valenza F, Lipton JM, Gattinoni L: Plasma concentrations and anti-L-cytokine effects of alpha-melanocyte stimulating hormone in septic patients. Crit Care Med 2000, 28:1403-1407.

78. Rittirsch D, Hoesel LM, Ward PA: The disconnect between animal models of sepsis and human sepsis. J Leukoc Biol 2007, 81:137-143

79. Esmon CT: Why do animal models (sometimes) fail to mimic human sepsis? Crit Care Med 2004, 32:S219-222.

80. Poli-de-Figueiredo LF, Garrido AG, Nakagawa N, Sannomiya P: Experimental models of sepsis and their clinical relevance. Shock 2008, 30(Suppl 1):53-59.

81. Crane JW, Buller KM: Systemic blockade of complement C5a receptors reduces lipopolysacharride-induced responses in the paraventricular nucleus and the central amygdala. Neurosci Lett 2007, 424:10-15. 